\begin{tabular}{lcr}
\hline & ANNALES \\
& UNIVERSITATIS MARIAE CURIE-SKŁODOWSKA & \\
LOL. I & LUBLIN - POLONIA & 2016 \\
\hline
\end{tabular}

Dominika Mikucka-Wójtowicz

University of Warsaw

\title{
The 2014 Parliamentary Elections in Serbia - Refresh or Reset of the Political Landscape?
}

\section{Background}

On 16 March, less than two months after the beginning of negotiations on accession to the EU, early parliamentary elections took place in Serbia, the sixth since the democratic opposition came to power in 2000. The parliament elected in May 2012 was dissolved on 29 January on the strength of a decision by President Tomislav Nikolić. This also marked the beginning of the election campaign, which continued until 48 hours before voting commenced. The head of state's decision to dissolve the Skupština was based on the government motion which stated that painful reforms were in store for Serbia and that new legitimisation from voter was vital in order to implement them. The main initiator of the early elections was the leader of the Serbian Progressive Party (SNS), Aleksandar Vučić. On 24 January, during an extraordinary SNS electoral convention at which he was re-elected as party leader, Vučić declared that it was time to test the trust and will of the voters ${ }^{1}$.

1 See N. Tomić, Vučić: Vreme je da proverimo volju naroda!, "Danas”, 24 I 2014, http://www. danas.rs, access: 23 III 2014; J. Gligorijević, Izborna skupština SNS: Tamo gde je sve po mom, "Vreme", 30 I 2014, no. 1204, http://www.vreme.com, access: 23 III 2014. 
After 2012 elections, the core of the ruling coalition was somewhat unexpectedly made up by the Serbian Progressive Party - at the time headed by Tomislav Nikolić, who was elected head of state in presidential elections held at the same time - along with members of the Serbian Socialist Party/Party of Pensioners/United Serbia (SPS-PUPS-JS) election coalition, in which the SPS, the post-Milošević party led by Ivica Dačić, was the major player. After the elections, the Socialist leader used a ploy tried out in $2008^{2}$. At first he held talks with Boris Tadićs Democratic Party (DS), with which he had formed a government in 2008-2012, but after a few weeks decided to change his strategy and began discussions with the SNS, who, although the Socialists had only gained third place in the elections (with $14.5 \%$ of votes), agreed to entrust Dačić with the prime minister's portfolio ${ }^{3}$. However, experts in Serbia were almost unanimous in their opinion that despite the symbolic concession to the SPS, it would be the SNS and its new leader Aleksandar Vučić who would play the dominant role in the coalition. Vučić assumed the function of first deputy prime minister (Prvi Potpredsednik Vlade - PPV), which has no basis in the Serbian constitution or political tradition ${ }^{4}$. A further major surprise was caused by the invitation of Mlađan Dinkić's United Regions of Serbia (URS) party. Dinkić became minister of finance and the economy, which was interesting as during the election campaign he had been made a scapegoat by the Progressives, who had accused him of driving the Serbian economy to collapse ${ }^{5}$.

The main successes of the 18-month-long SNS-SPS government (in which one reshuffle took place in this time) in fact only include achievements in foreign policy. In particular, this meant efforts to normalise relations with Kosovo, a measurable effect of which was the signing of the so-called Brussels Agreement by the prime ministers of Serbia and Kosovo on 19 April 2013. This occurred after several months of often tempestuous negotiations mediated by EU foreign policy chief Catherine Ashton. Without doubt, this fact also contributed to the Serbian government's officially opening accession negotiations with the EU on 21 January 2014.

2 Then, the Socialists had initially held talks on forming a government with the anti-EU radicals from the SRS, before ultimately deciding to enter a pro-European coalition government with the DS and G17 Plus.

3 See D. Bochsler, The parliamentary election in Serbia, 21 January 2007, "Electoral Studies", 2008, no. 27 (1), pp. 160-165; A. Konitzer, The parliamentary elections in Serbia, May 2012, "Electoral Studies", 2013, no. 32 (2), pp. 380-385.

4 The website of the Paragraf Lex, http://paragraflex.com, "Neustavna funkcija zamenika predsednika Vlade", access: 23 III 2014.

5 Dinkić was dismissed in July 2013, and the "super-ministry" which he oversaw was split in two. 
Dačić's cabinet did not fulfil its promises for widespread economic reforms, however, and neither did it implement the so-called Marshall Plan for Serbia, which vice-premier Aleksandar Vučić announced in August last year 6 . On 24 January, Minister for the Economy Saša Radulović, an independent technocrat, resigned, accusing Vučić and his closest colleagues of blocking the comprehensive package of reforms adapted to IMF requirements he had prepared (these included the labour law and the law on privatisation). Radulović also stressed that Vučić frequently stepped outside of his remit in his actions, ignoring the democratic institutions. The government reforms in the health service and education met with criticism from experts, who accused them of inconsistency, for example passing bills without the executive acts required ${ }^{7}$. Meanwhile, the battle with corruption and Serbian oligarchs (taykuns), despite boosting the first vice-premier's popularity, also often took the form of revenge on political opponents (e.g. the mass arrests of DS opposition politicians) and was waged by unqualified institutions, in particular the administrative office of the first deputy prime minister. It was also dominated by media witch-hunts in tabloids close to the Progressives ${ }^{8}$.

\section{Electoral system and administration}

Since 1992, Serbia has had a proportional electoral system in which votes are cast for closed lists, and since 2000 the whole country has formed one constituency. An election threshold of 5\% is in place, although following the 2004 reforms this requirement no longer applies to national minority parties. The D'Hondt method, which favours strong parties, is used in counting votes to decide on allocation of seats. The last significant changes in the electoral system were made in 2011. Two changes were made following great pressure from the EU. First, the regulation introduced to the statute in 2000, which granted party leaders complete autonomy in assigning the seats won by a given party, for which they had as many as 10 days following announcement of the results, was repealed. Second, the practice of deputies signing so-called blank resignation letters ("blanko ostavke"), a mechanism used by party leaders to keep them

6 A. Vučić, Imam Maršalov plan za Srbiju, "Kurir”, 15 VIII 2013, http://www.kurir.rs, access: 15 VIII 2013.

BIRN, Izveštaj o učinku rada vlade: jul 2012 - januar 2014. godine, Beograd 2014.

8 See BIRN, Izveštaj...; M. Milošević, Vanredni izbori 2014.: Bitka pred praznom kasom, "Vreme", 30 January 2014, no. 1204, http://www.vreme.com, access: 23 III 2014 ; I. Milanović Hrašovec I., Intervju - Srbijanka Turajlić, profesorka: Svi na izbore, "Vreme”, 23 I 2014, no. 1203, http://www.vreme.com, access: 23 III 2014; B. Trivić, Intervju - Vesna Pešić: Vučićeva vladavina je suštinski antisistemska, "Radio Slobona Evropa", 2 III 2014, http://www.slobodnaevropa.org, access: 23 III 2014. 
tightly in check, was abolished. Since 2011, the seats which individual parties gain in elections are divided on a top-down basis by the Republic Electoral Commission (RIK) according to the order stipulated by electoral lists. Furthermore, the regulations whereby $30 \%$ of the places on these lists are guaranteed to the lesser represented sex - generally women - were made more specific. Finally, following almost a decade of work, an electronic electoral list began to operate, which made it possible to detect cases of voters being registered in several districts, and checks of parties' election campaign financial reports were handed over to the Anti-Corruption Agency appointed in 2010. Such procedures had previously been entrusted to the politicised RIK and therefore largely fictitious ${ }^{9}$.

\section{The main contenders}

A total of 19 lists were registered in the March elections (compared to 18 in 2012), with 3020 candidates (12 per available seat), including 1087 (36\%) women. Some 40 parties, social movements, associations and trade unions were represented.

Commentators deemed the election campaign extremely boring in terms of party programmes ${ }^{10}$. However, it was teeming with often surprising examples of changes to the previous inter-party alliances as well as splits, which demonstrated the extremely weak institutionalisation of the party system.

The prelude to the reshuffles on the political scene was a press conference called on 30 January by former president Boris Tadić, who announced that he was leaving the Democrats. This came as a particular surprise as only a week earlier (21 January), during a sitting of the Central Board of DS, he had stated repeatedly that he did not intend to leave the party, despite not succeeding in forcing a vote of no-confidence on the current president Dragan Đilas. During the conference, the former president did not rule out participating in the elections, but made it clear that he would not have time to form a new party. However, he again soon changed his mind, and on 9 February the founding meeting of his New Democratic Party (NDS) took place. Yet indeed he did not form a new group, instead becoming leader of the Greens of Serbia party, which then applied to the ministry to change its name to New Democratic

9 See A. Konitzer, op. cit., p. 381; D. Mikucka-Wójtowicz, Ewolucja systemu wyborczego Serbii w latach 1990-2011. Od manipulacji do demokratyzacji, "Studia Polityczne", 2012, no. 30, pp. 100-101; 102-103.

10 The website of the Radio Slobodna Evropa, http://www.slobodnaevropa.org, "Izborna kampanija u Srbiji: ništa ni o čemu", access: 23 III 2014; D. Boarov, Predizborna ekonomija: bilioni, kanali i bal na vodi, "Vreme", 16 I 2014, no. 1202, http://www.vreme.com, access: 23 III 2014. 
Party - Greens ${ }^{11}$. The NDS registered a coalition list for the elections, which, along with Tadićs close allies who had followed him in leaving the DS, also featured representatives of five other, small parties. Somewhat surprisingly, this included Nenad Čanak's League of Social Democrats of Vojvodina (LSV), previously a coalition partner of the Democrats.

It was the Progressives of the SNS, though, who had the greatest coalition potential. Using the slogan "Future we believe in", they had managed to attract several of their rivals' major partners. In addition to the coalition partners from the previous elections - the New Serbia (NS) led by Velimir Ilić and the Movement of Socialist (PS) led by Aleksandar Vulin - the SNS lists also featured Rasim Ljajić's Social Democratic Party of Serbia (SDPS) (since 2000 Ljajić and the two parties which he led had always been on DS lists) and Vuk Drašković's Serbian Renewal Movement (SPO). In the previous elections, the SPO and Čedomira Jovanović's Liberal Democratic Party (LDP) - often described as Euroenthusiast - had formed the core of the U-Turn (Preokret) coalition. This time, Jovanović formed a coalition with Žarko Koraćs Social Democrats and the Bosniak Democratic Commuity of Sandžak (BDZS). The latter, the party of the controversial mufti of Sandžak, Muamer Zukorlić, had little in common with the former politically, and was more likely to scare liberal voters away. Furthermore, whereas the LDP's campaign was aimed strongly against Dačićs Socialists, the party leader did not rule out the possibility of forming a postelection alliance with the SNS.

On the other hand, one of the few parties to reject the possibility of forming such alliances with the Progressives was the Democratic Party, which, weakened by Boris Tadićs exit, entered a coalition with the New Party led by Zoran Živković. This alliance, which had been announced earlier by Dragan Đilas, was cited by the former president as one of the reasons for his departure from the Democrats. Tadić accused Živković of misappropriation of funds and claimed that in the short time when he had been prime minister (20032004) his policies had led to the DS being seen as a party riven by corruption scandals ${ }^{12}$.

One party that did remain faithful to its previous strategy was the Socialists of Prime Minister Dačić, who for the third time were at the forefront of a SPS-PUPS-JS election coalition. Vojislav Koštunica's national conservative Democratic Party of Serbia (DSS), as in 2012, was one of few parties to go

11 At the beginning of April the process of division of the parties began, and their leaders started to wrangle over who had the rights to the name, and consequently which grouping would have to reregister.

12 Tadić izašao iz DS, “Danas”, 30 I 2014, http://www.danas.rs, access: 30 I 2014. 
into the elections independently. In the previous elections, incidentally, it had been the only one to exceed the electoral threshold on its own. The SRS and the Dveri civic movement also ultimately opted to post separate lists, having initially considered forming a coalition. In spite of the similarity of their programmes, they had proven unable to come to an agreement. Among the new groups which interested the media and public opinion was the "Enough of That" ("Dosta je bilo") list of Minister of the Economy Saša Radulović. We should mention that before this list was formed, there was speculation that Radulović would be running from the list of a party representing the Slovakian minority. The fact that minority parties are not bound by the $5 \%$ election threshold, but only the natural threshold, would have meant that his chances of entering the Skupština were greater.

\section{The campaign}

Amid the comings and goings on the party scene, the campaign itself was remarkably tepid. The parties spent (not to say wasted) much of it concerned with their own internal problems and not always successful public relations moves. A spectacular example of a PR gaffe from the start of the campaign was the so-called Feketić case, when Aleksandar Vučic tried to rescue passengers from a snowbound bus. The short footage of the incident shown by public television was then turned by the satirist Srđan Miletić into an irreverent clip which was quickly taken down from YouTube. This situation was repeated every time it was uploaded to the site. The SNS of course denied any involvement. However, the party already had similar gaffes to its name from messages posted on Twitter. It is therefore hardly surprising that this affair led to questions of whether the authorities had gone too far and infringed freedom of speech $^{13}$.

The parties' election programmes were far from impressive. Given the torrid situation in which the Serbian economy finds itself (many local and foreign economists went so far as to warn that any further dallying with economic reforms would mean the threat of bankruptcy), it is no surprise that this was the issue that dominated the campaign ${ }^{14}$. But the subject that was most conspicuous by

13 J. Gligorijević, Izbori i cenzura: Hrani Simu pa šalji na Tviter - internet se umiriti ne može, "Vreme", 6 II 2014, no. 1205, http://www.vreme.com, access: 23 III 2014.

14 See the website of the "Deutsche Welle", http://www.dw.de, "Nemčka štampa: Vučić sada mora da se pokaže”, 17 III 2014, access: 26 III 2014; R. Marković, Ekonomija u postizbornom periodu: Kakve su reforme potrebne Srbiji, "Vreme", 20 II 2014, no. 1207, http://www.vreme.com, access: 23 III 2014. 
its absence, even deftly avoided, was the future of Kosovo. This was particularly interesting as the elections in Serbia coincided with the unilateral declaration of independence by the Crimean authorities in Ukraine.

It is no exaggeration to describe the campaign as one of empty slogans. All the parties spoke of the need to battle the crisis and growing unemployment, advocating restructuring and privatisation of state-owned enterprises. On the whole, though, these were very general promises, without mention of the means to be used to fulfil them. Similar slogans had also been dominant before the 2012 elections. Moreover, politicians often resorted to populist declarations in order to attract voters. The minister of energy and mining, for example, announced a 10-billion wave of Chinese investments (later explaining this much overstated amount by saying that it was a mistake in the translation from the English). SNS leader Aleksandar Vučić, meanwhile, pushed through the project of building a so-called Belgrade on the water (a recycled version of the "Europolis" project endorsed in the mid-1990s among others by Mira Marković, the wife of President Milošević), in which a major share of the funding was to be provided by sheikhs from the United Arab Emirates. The proposals of just two parties stood out amid these nebulous promises. The first was the economic programme proposed by Saša Radulović's Enough of That party, based on the reform package which he prepared before his resignation. The second exception, familiar from the previous elections, was the programme of military and political neutrality of Vojislav Koštunica's DSS.

Despite their PR blunder at the start of the campaign, it ended in great success for the Progressives. Aleksandar Vučić made clever use of the type of populist calls that are more characteristic of parties only aspiring to power. The leader of the Progressives assured voters of his dedication to repair the country and asked them to show support for the SNS. He also threatened that if they did not manage to obtain an absolute majority of votes, the other parties would soon unite against the Progressives and block their proposed reforms, which Serbia needed, painful as they would be ${ }^{15}$. As the election results showed, his appeals succeeded.

\section{Results}

Although Serbian experts agreed that the early elections constituted a form of referendum for and against Vučić and the SNS, and polls gave the Progressives

15 The website of the "Dnevnik", http://www.dnevnik.rs, "Vučić: Za reforme nam je treba 50\% podrške građana”, 21 February 2014, access: 23 III 2014. 
a significant advantage over other parties, there were at least several reasons for which their results came as quite a surprise ${ }^{16}$.

Firstly, the coalition list which the Serbian Progressive Party put its name to gained the support of $48.35 \%$ of voters (Table 1), i.e. over twice the amount from the previous election cycle (24.04\%). Only the DOS coalition in 2000 had achieved a better result, with $64.4 \%$ of the votes ${ }^{17}$. The support for the SNS list in the March elections translated into 158 seats (out of a total of 250), some 32 more than the majority needed to form an independent government. In accordance with the coalition agreement and the order of candidates on the election lists, the Progressives gained 136 seats and their coalition partners 22. This meant that even if all the SNS's coalition partners were to leave, it would still retain a sufficient majority to maintain a one-party government. Furthermore, of all the groupings which made it to parliament, only the DS, with 19 seats, stated that it did not intend to form a government with the Progressives.

Secondly, both politicians and political columnists described the election results as a "tsunami", "tectonic changes" or an "earthquake" on the party scene. Election mandates were gained by a total of seven of the 19 lists, including three parties representing national minorities (Ištvan Pastor's SVM - Hungarian, Sulejman Ugljanin's SDA - Bosniak and Riza Halimi's PPD - Albanian). The new deputies formed 12 parliamentary groups, and two retained the status of independent members of parliament. Three groupings previously considered relevant lost their parliamentary status as a result of the elections: the nationalconservative DSS, which had had deputies in the Skupština continuously since 1992, as well as the liberal LDP and URS ${ }^{18}$, present in parliament for a decade less. Analysing the election results and the campaign that went before, though, equally surprising as the success of Boris Tadić's newly formed New Democratic Party is the fact that Vojislav Koštunica's DSS failed to gain seats. This was despite its long tradition and a programme conception markedly different from the mainstream parties (for several years consistently proposing political and military independence and fighting to keep Kosovo within Serbia). Furthermore, for the second time in a row the Progressives' parent party the Serbian Radical Party (SRS), which in 2003-2008 had enjoyed the most stable support, hovering around $30 \%$, failed to break the threshold. The main reason stopping

16 I. Milanović-Hrašovac, Intervju Srećko Mihailović, socijolog: fama o hapšenjima, kadrovima, reformama, "Vreme", 27 II 2014, no. 1208, http://www.vreme.com, access: 23 III 2014.

17 The SPS in 1990 in fact received more seats than the SNS, but this was with the help of a majority election system. They thus had 194 deputies in the Skupština, despite only having received $46.1 \%$ of the popular vote (with a turnout of $71.5 \%$ ).

18 A. Konitzer, op. cit., p. 382. 
the Radicals from forming a government at the time had been signals from the European Union institutions that such a cabinet would block any chances of Serbian integration with the EU. The party's latest failure in the March elections suggests that despite the significant ideological differences (the official reason for the SRS's schism in October 2008 was the incompatibility of Nikolić and Šešelj's positions regarding European integration), the Progressives managed to inherit their parent party's electorate.

Thirdly, one should note that there was no anti-EU party in parliament following the most recent elections. This is in spite of the fact that studies conducted in December 2013 on behalf of the Serbian European Integration Office (SEIO) showed that $22 \%$ of Serbs are against further integration with the European Union ${ }^{19}$. It is therefore indeed difficult to claim that the parliament was fulfilling its function as a mirror of society, since one fifth of voters were not represented. This situation is even more interesting as after the 2008 elections, when the integration issue had been an important topic of the campaign, antiEU parties obtained almost $42 \%$ of votes (if as well as the SRS we also count the DSS, which took a much more radical line at this point), whereas only $13 \%$ of citizens were against integration at the time ${ }^{20}$.

Fourthly and finally, we should not ignore the fact that voter turnout at the March elections was at its lowest in the 24 years that have elapsed since the multi-party system was revived in Serbia. Only 53.12\% of eligible voters went to the ballot boxes. Without doubt, Aleksandar Vučić proved more effective than his competitors at mobilising his electorate. However, we can hardly speak of a ringing endorsement for the SNS, bearing in mind the correlation of the Progressives' results and the turnout. In reality, only a quarter of those eligible to vote did so for the party.

19 The website of the SEIO, http://www.seio.gov.rs, "Evropska orientacija građana Srbije. Ispitivanje jevnog mnjenja (decembar 2013. godine)", access: 30 IV 2014.

20 The website of the SEIO, http://www.seio.gov.rs, "Evropska orientacija građana Srbije. Trendovi. Predstavljanje rezultata istraživanja javnog mnjenja (decembar 2008. godine)”, access: 30 IV 2014. 


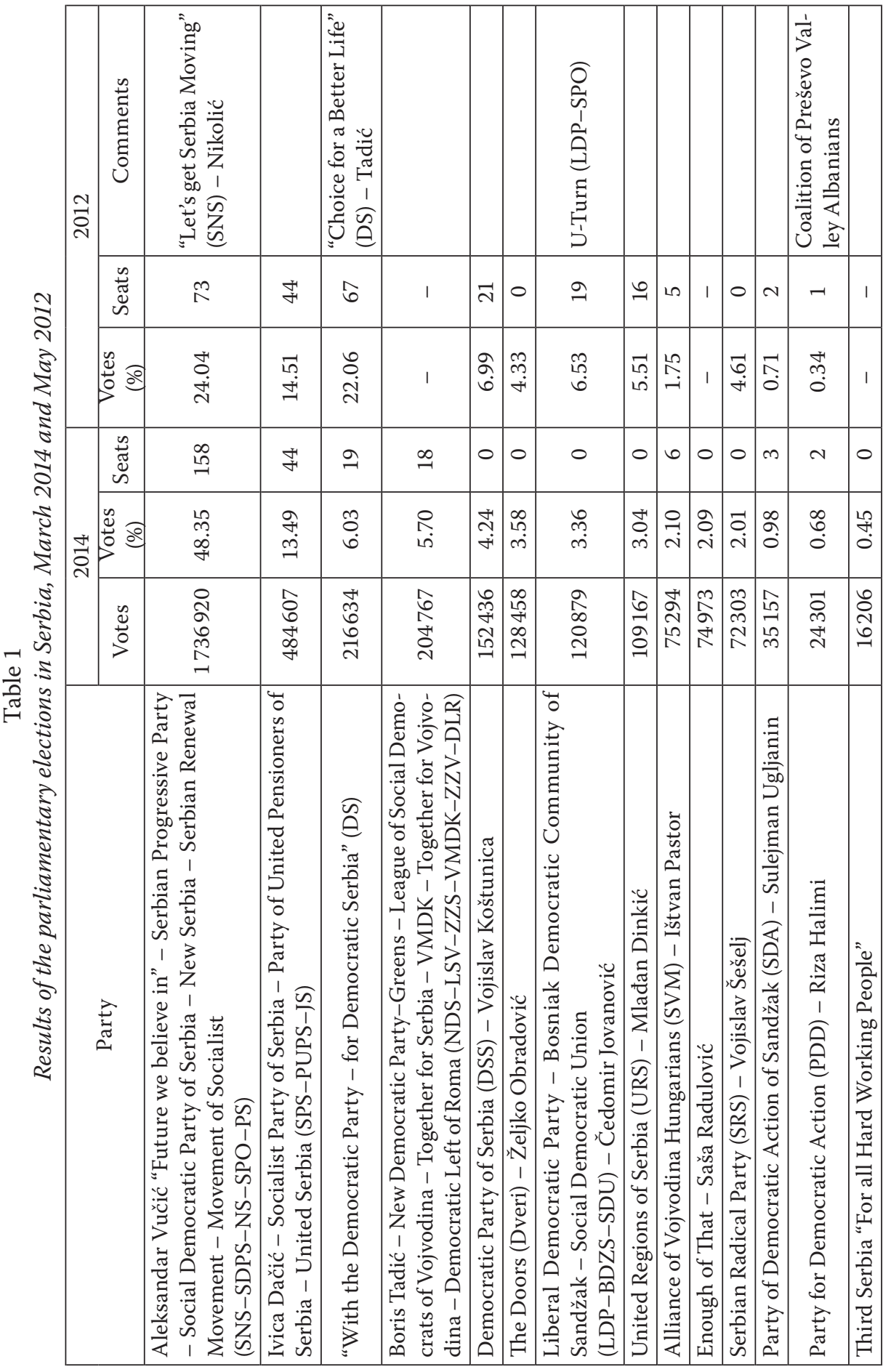




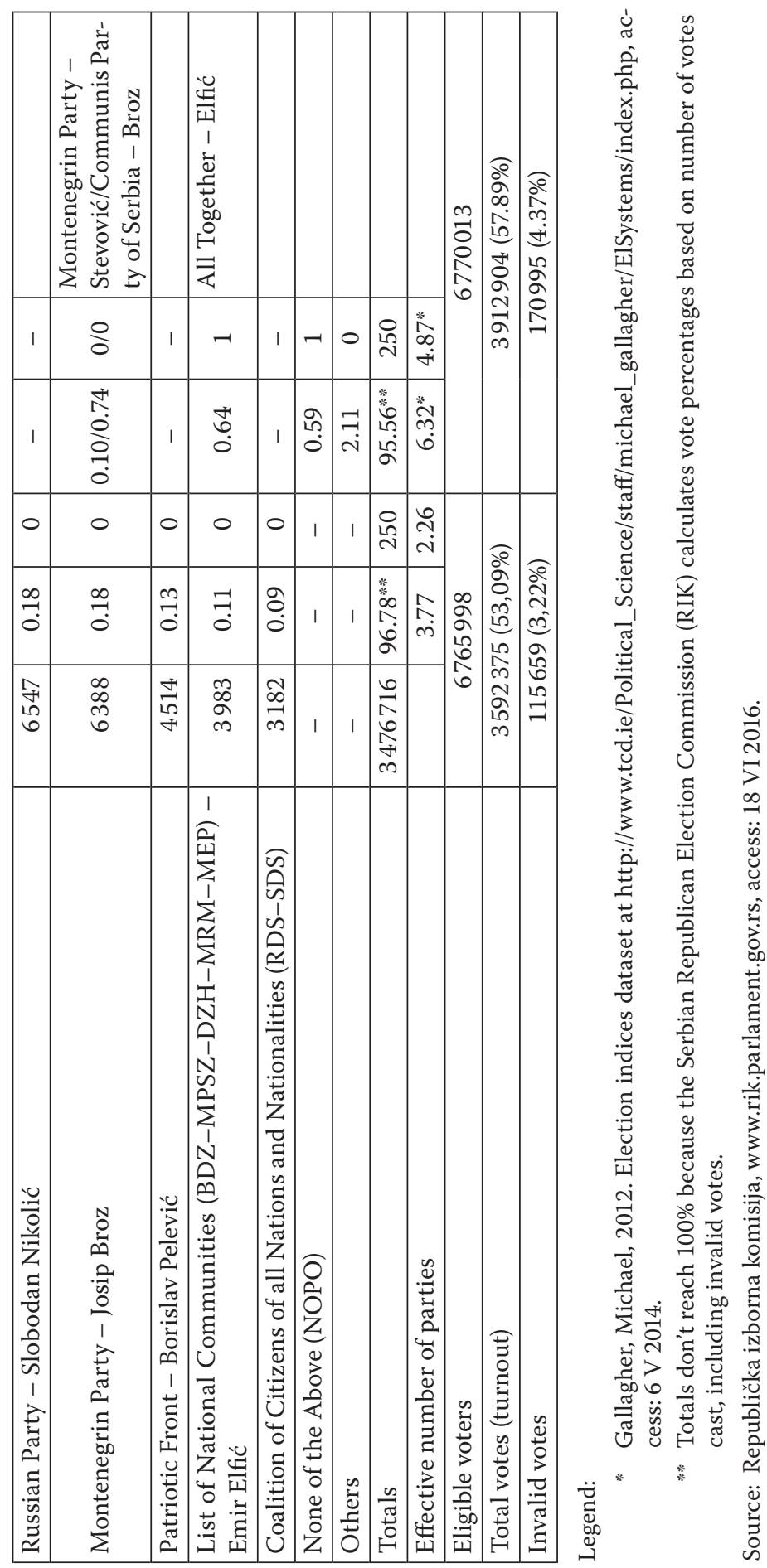




\section{Formation of government}

Despite the Progressives' clear victory, Aleksandar Vučić declared his openness to forming a coalition cabinet with the leaders of all parties that had won seats in parliament, which perhaps shows that he was keen to "mask" responsibility for the actions of the future government. But before engaging in any talks, the SNS leader set about writing a "programme for Serbia". Just last summer he had announced that he was close to completion of the so-called Marshall Plan for Serbia, which was supposed to both identify the goals set by the government and set out in detail reform proposals and the dates by which they should be introduced. The official discussions on appointing a new government began only a month after the elections. Before this, of course, there was much speculation in the media on the shape that the future cabinet would take and rhetoric of the various leaders whose parties had gained seats as to the positions they might be interested in taking in the government if the Progressives should invite them ${ }^{21}$.

Ultimately, the SNS was joined by the SPS and the Hungarian minority SVM in the new cabinet. Vučić also offered ministerial portfolios to the leaders of two parties from the Progressives' list: Velimir Ilić from the NS and Rasim Ljajić from the SDPS. The SVM, despite officially being part of the ruling coalition, does not have a minister in it, instead being given secretarial positions in several ministries. This was incidentally in line with wishes of party leader Ištvan Pastor. As for the SPS, although for a long time it looked like the chances of rebuilding the SNS-SPS coalition had in fact evaporated, in the end the Socialists were included in the new cabinet ${ }^{22}$. The Progressives made it clear, however, that ministerial positions would be open only to SPS members, not those of its coalition partners the PUPS and JS. Aleksandar Vučić also held talks with NDS leader Boris Tadić. Yet media speculation about the likelihood of the NDS joining the government and its leader becoming a minister proved unfounded. Tadićs claims that he did not want to be in government with the Socialists may well have had a role to play in this ("Politika" 2014) - they at least gave the Progressives a convenient excuse $^{23}$. It would appear that Vučić made clever use of Tadić to break up and weaken the opposition DS, to the benefit of the Progressives. History was in

21 M.R. Milenković, Samo 19 resora, a ogroman broj zainteresovanih, "Danas”, 11 IV 2014, http://www.danas.rs, access: 11 IV 2014.

22 S. Čongradin, Vrata vlasti polako se zatvaraju za SPS, “Danas”, 27 III 2014, http://www. danas.rs, access: 27 III 2014.

23 Vučić $i$ Tadić postigli su saglansot o ključnim pitanjima, "Politika", http://www.politika.rs, access: 10 IV 2014. 
a way repeating itself here, as Tadić had played a similar role in 2008 at the time of the split in the Radicals camp and emergence of the SNS.

The new government was sworn in on 27 April. In favour were 198 deputies, 23 voted against, with one abstention. The new cabinet was formed by 19 members apart from the prime minister, including two ministers without portfolio. Six ministries went to the SNS: construction, transport and infrastructure (overseen by the SPS vice-president Zorana Mihajlović, who is also deputy prime minister, and in Dačić's government was minister for energy); justice (Nikola Selaković remained in this position); sport (which Vanja Udovički continued to hold); health; defence; and domestic affairs. The SNS also has one minister without portfolio, Jadranka Joksimović, who is responsible for coordinating the process of European integration. The Socialists took three ministries. The SPS leader Ivica Dačić became first deputy prime minister and minister of foreign affairs. Energy and mining as well as agriculture and environmental protection were the other departments awarded to them. The SDPS leader Rasim Ljajić became minister of trade, telecommunications and tourism. Aleksander Vulin of the PS assumed the office of minister of labour, employment and social affairs, which was originally meant to go to Ljajić. The NS leader Velimir Ilić, meanwhile, became a minister without portfolio responsible for extraordinary events. Five independent technocrats also joined the government, entering the ministries of administration and local government, finance (with Lazar Krstić remaining at the helm), the economy, culture (again Ivan Tasovac) and education, science and technological development. Half the ministers had also been part of Dačićs cabinet, so it is hardly surprising that it was called the "new-old government".

Aleksandar Vučić identified the economic crisis as the main priority of the new cabinet, with the struggle against it concentrating on three pillars. First, a package of economic reforms that would help eliminate corruption, lead to establishment of a free market in Serbia and serve to attract new investments. Second, the government is to take decisive action to support the development of the private sector. The priority is to be backing for small and medium-sized enterprises, which will play a key role in the fight against unemployment. Third, the prime minister announced budget consolidation, in particular by reducing expenditure and increasing revenue. The additional income is to help raise living standards, develop education and science, and improve the situation in the health service. It is expected to derive largely from funds gained thanks to privatisation of leading Serbian companies including the Telekom mobile telephone network, the energy concern Elektrprivreda Srbije and the insurance firm Dunav osiguranje. The prime minister also announced (incidentally, such promises are delivered after every election) that some funds would be saved by 
reduction of employment in the public administration. Those facing redundancy would be people who had received their jobs thanks to party connections. As for foreign policy, the main objectives are to complete accession negotiations with the EU by the end of the current parliament's term of office (i.e. 2018) and secure accession in 2020, as well as further normalisation of relations with Kosovo. Prime Minister Vučić himself is to take personal charge of these negotiations. He gave assurances that the government is not open the possibility of recognising the territory's sovereignty (although unofficially it did this with the Brussels Agreement) ${ }^{24}$.

To quote Halid Bešlićs song "Miljacka" - "Who could have said that miracles would happen?" - which the current deputy prime minister famously sang during the 2012 election campaign, and looking at the foreign policy achievements of the previous SNS-SPS government, it seems increasingly probable that the party leaders who bore the greatest responsibility for Serbia's isolation in the 1990s and the armed conflicts of the time will bring the country into the European Union and lead to settlement of relations between Serbia and Kosovo. After all, similar "miracles" have happened in the Balkans before: the Croatian Democratic Union (HDZ)'s change in policies after it returned to power in 2003, to mention just one.

\section{Bibliography}

\section{Sources}

- BIRN, Izveštaj o učinku rada vlade: jul 2012 - januar 2014. godine, Beograd 2014, http://birnsrbija.rs.

- Boarov D., Predizborna ekonomija: bilioni, kanali i bal na vodi, "Vreme", 16 I 2014, no. 1202, http://www.vreme.com.

- Čongradin S., Vrata vlasti polako se zatvaraju za SPS, “Danas", 27 III 2014, http:// www.danas.rs.

- Gligorijević J., Izborna skupština SNS: Tamo gde je sve po mom, "Vreme”, 30 I 2014, no. 1204, http://www.vreme.com.

- Gligorijević J., Izbori i cenzura: Hrani Simu pa šalji na Tviter - internet se umiriti ne može, "Vreme", 6 II 2014, no. 1205, http://www.vreme.com.

- Marković R., Ekonomija u postizbornom periodu: Kakve su reforme potrebne Srbiji, "Vreme", 20 II 2014, no. 1207, http://www.vreme.com.

24 A. Vučić, Ekspoze predsednika Vlade Republike Srbije Aleksandra Vučića, http://www. srbija.gov.rs, access: 30 IV 2014. 
- Milanović-Hrašovac I., Intervju Srećko Mihailović, socijolog: fama o hapšenjima, kadrovima, reformama, "Vreme", 27 II 2014, no. 1208, http://www.vreme.com.

- Milanović Hrašovec I., Intervju - Srbijanka Turajlić, profesorka: Svi na izbore, "Vreme”, 23 I 2014, no. 1203, http://www.vreme.com.

- Milenković M.R., Samo 19 resora, a ogroman brojzainteresovanih, "Danas”, 11 IV 2014, http://www.danas.rs.

- Milošević M., Vanredni izbori 2014.: Bitka pred praznom kasom, "Vreme”, 30 I 2014, no. 1204, http://www.vreme.com.

- Najviša stopa nezaposlenosti od formiranja EU, "Blic", 2 VII 2012, http://www.blic.rs.

- Tadić izašao iz DS, "Danas", 30 I 2014, http://www.danas.rs.

- The website of the Deutsche Welle, http://www.dw.de, "Nemčka štampa: Vučić sada mora da se pokaže".

- The website of the Dnevnik, http://www.dnevnik.rs, "Vučić: Za reforme nam je treba $50 \%$ podrške građana".

- The website of the Paragraf Lex, http://paragraflex.com, "Neustavna funkcija zamenika predsednika Vlade".

- The website of the Radio Slobodna Evropa, http://www.slobodnaevropa.org, "Izborna kampanja u Srbiji: ništa ni o čemu".

- The website of the SEIO, http://www.seio.gov.rs, "Evropska orientacija građana Srbije. Trendovi. Predstavljanje rezultata istraživanja javnog mnjenja (decembar 2008. godine).

- The website of the SEIO, http://www.seio.gov.rs, "Evropska orientacija građana Srbije. Ispitivanje jevnog mnjenja (decembar 2013. godine)".

- Tomić N., Vučić: Vreme je da proverimo volju naroda!, "Danas”, 24 I 2014,. http:// www.danas.rs.

- Trivić B., Intervju - Vesna Pešić: Vučićeva vladavina je suštinski antisistemska, "Radio Slobona Evropa", 2 III 2014, http://www.slobodnaevropa.org.

- Vučić A., Imam Maršalov plan za Srbiju, "Kurir", 15 VIII 2013, http://www.kurir.rs.

- Vučić A., Ekspoze predsednika Vlade Republike Srbije Aleksandra Vučića, http:// www.srbija.gov.rs.

- Vučić i Tadić postigli su saglansot o ključnim pitanjima, "Politika”, 10 IV 2014, http:// www.politika.rs.

\section{Literature}

- Bochsler D., The parliamentary election in Serbia, 21 January 2007, "Electoral Studies", 2008, no. 27 (1).

- Konitzer A., The parliamentary elections in Serbia, May 2012, "Electoral Studies", 2013, no. 32 (2).

- Mikucka-Wójtowicz D., Ewolucja systemu wyborczego Serbii w latach 1990-2011. Od manipulacji do demokratyzacji, "Studia Polityczne”, 2012, no. 30. 
Summary: The article is devoted to the early parliamentary elections in Serbia, which took place on 16 March 2014, less than two months after the beginning of negotiations on accession to the EU. The parliament elected in May 2012 was dissolved on 29 January on the strength of a decision by President Tomislav Nikolić. The head of state's decision to dissolve the Skupština was based on the government motion which stated that painful reforms were in store for Serbia and that new legitimisation from voter was vital in order to implement them. The main initiator of the early elections was the leader of the Serbian Progressive Party (SNS) and the first deputy prime minister, Aleksandar Vučić, who wanted to consolidate his power.

Keywords: Serbia, parliamentary elections, early elections

\section{Wybory parlamentarne w Serbii w 2014 roku - odświeżenie czy reset krajobrazu politycznego?}

Streszczenie: Artykuł jest poświęcony analizie przedterminowych wyborów parlamentarnych w Serbii, które odbyły się 16 marca 2014 roku, czyli niespełna dwa miesiące po rozpoczęciu przez serbski rząd negocjacji w sprawie przystąpienia do Unii Europejskiej. Parlament, wybrany w maju 2012 roku, został rozwiązany 29 stycznia na mocy decyzji prezydenta Tomislava Nikolicia. Tym samym głowa państwa przychyliła się do wniosku zgłoszonego przez rząd, w którym podnoszono, że do przeprowadzenia koniecznych, aczkolwiek bolesnych, reform niezbędne jest uzyskanie nowej legitymacji od wyborców. Głównym inicjatorem przedterminowych wyborów był lider Serbskiej Partii Postępowej (SNS) i pierwszy wicepremier Aleksander Vučić, który liczył na umocnienie w ich następstwie swojej władzy.

Słowa kluczowe: Serbia, wybory parlamentarne, przedterminowe wybory 